\title{
PENGARUH PENGGUNAAN STRATEGI MODELING SIMBOLIK DALAM BIMBINGAN KELOMPOK TERHADAP PEMAHAMAN KARIER SISWA KELAS X SMK AL-ISLAH SURABAYA
}

\author{
Lurian Magendra \\ Program Studi Bimbingan Konseling Fakultas Keguruan dan Ilmu Pendidikan \\ Universitas PGRI Adi Buana Surabaya \\ Email: hay.bigluri@yahoo.co.id \\ Boy Soedarmadji \\ Program Studi Bimbingan Konseling Fakultas Keguruan dan Ilmu Pendidikan \\ Universitas PGRI Adi Buana Surabaya \\ Email: boyunipasby@gmail.com
}

\begin{abstract}
The purpose of this research is to find out the influence of using modeling symbolic strategy in group guidance to career understanding of the student $10^{\text {th }}$ class SMK AL ISLAH Surabaya. The research design used one group pretestposttest design using samples 14 students. The results using technique of modeling symbolic in group guidance with a percentage increase of 30,92\%. The conclusion technique of modeling symbolic in guidance group can increase career understanding of student in $10^{\text {th }}$ class SMK AL-Islah Surabaya.
\end{abstract}

Keywords: Modeling Symbolic on group guidance, Career Understanding

\section{PENDAHULUAN}

Pendidikan merupakan faktor penting dalam pembangunan dan menjadi pondasi dasar dalam kemajuan suatu negara khususnya di Indonesia. Menurut undang-undang nomer 20 tahun 2003, pendidikan merupakan usaha sadar dan terencana untuk mewujudkan suasana belajar dan proses pembelajaran agar perserta didik secara aktif mengembangkan potensi dirinya untuk memiliki kekuatan spiritual keagamaan, pengendalian diri, kepribadian, memiliki kecerdasan berakhlak mulia, serta memiliki keterampilan yang diperlukan sebagai anggota masyarakat, bangsa dan negara. Dalam bidang pendidikan, bimbingan karier merupakan salah satu dari program bimbingan dan 
konseling. Perserta didik (siswa) dituntut untuk dapat mengembangkan dan menguasai berbagai kemampuan,baik yang berhubungan dengan mata pelajaran, pengembangan diri, dan karier kehidupannya.

Hasil peneletian yang dilakukan oleh Khoiriyah dan Nursalim (2012) diketahui bahwa pemberian tindakan layanan informasi yang dilakukan memberi perubahan yang signifikan terhadap pemahaman karier siswa. Hal ini ditunjukan dengan skor rata-rata angket pemahaman karier siswa yang semakin meningkiat dari pretest skor rata-rata angket pemahaman karier siswa sebesar $69,84 \%$ maka setelah siklus I naik menjadi $74,79 \%$ dan meningkat lagi menjadi $80,15 \%$ setelah siklus II (http://www.scribd.com/doc/1248781 57, diakses 14 Agustus 2014 pukul $01.00 \mathrm{WIB}$ ).

Dalam bimbingan dan konseling terdapat suatu strategi yaitu Penokohan (Modeling) yang mana strategi ini dapat digunakan dalam memberikan informasi karier pada siswa SMK seusai dengan bakat dan minat, dengan cara menunjukan tokoh nyata, tokoh melalui film, atau tokoh imajinasi sesuai dengan karier yang akan siswa tersebut pilih. Yang mana melalui pengamatan terhadap tokoh, peserta didik (siswa) terdorong untuk melakukan sesuatu yang mungkin sudah diketahui atau dipelajari dengan harapan tidak ada hambatan dalam pemilihan kariernya kelak. Dari uraian di atas maka peneliti tertarik untuk melakukan penelitian tentang pengaruh strategi modeling simbolik terhadap pemahaman karier siswa.

\section{METODE}

Penelitian ini merupakan penelitian pra-eksperimental dengan rancangan One Group PretestPosttest Design, yang bertujuan untuk mengetahui taraf signifikansi pengaruh penggunaan strategi modeling terhadap pemahaman karier siswa. Populasi pada penelitian ini adalah seluruh siswa yang menjadi target penelitian, yaitu sebanyak 92 siswa-siswi. Hanya siswa-siswi yang sedang mengalami masalah pemahaman karier yang rendah saja yang mendapatkan treatment strategi modeling, yaitu 
siswa-siswi kelas X MM 1, X MM 2, dan X MM 3. Peneliti mengambil sampel penelitian dengan teknik purposive sampling, Menurut arikunto (2010) purposive sampling (sampel bertujuan) dilakukan dengan mengambil subjek penelitian bukan didasarkan atas strata, random atau daerah tetapi didasarkan atas adanya tujuan tertentu.Dari penyebaran angket kepada populasi penelitian, diperoleh hasil siswa-siswi yang memiliki pemahaman karier yang rendah sebanyak 14 siswa.

Dalam penelitian ini datadata yang diperoleh merupakan data kualitatif dan kuantitatif. Data kualitatif didapat dengan menggunakan teknik nontes, yaitu suatu alat pengumpul data untuk mengetahui karakteristik, dengan hasil data yang berupa pernyataan, yaitu berupa angket, interview, dan dokumentasi. Penelitian ini mendapat data kualitatif dengan menggunakan interview, observasi dan dokumentasi, sedangkan data kuantitatif diperoleh dengan mempergunakan skala pengukuran pemahaman karier yang dikembangkan dengan skala likert.
Skala

pengukuran pemahaman karier telah dilakukan uji coba (try out) kepada kemudian hasilnya dianalisis dengan korelasi butir-total. Analisis korelasi butirtotal dimaksudkan untuk menguji validitas butir dengan ketentuan suatu butir dinyatakan valid jika koefisien korelasinya positif dan signifikan ( $p \geq 0,3$ ) (Azwar, 2013). Analisis korelasi butir-total skala pengukuran pemahaman karier menggunakan program SPSS for MS Windows versi 16.0. hasil analisisnya dari 60 butir soal diperoleh 38 soal yang valid. Uji validitas ini dilakukan terhadap 92 siswa kelas X SMK AL Islah yang diambil secara acak. Sedangkan untuk hasil uji reliabilitasnya adalah sebesar 0.893 .

Penelitian ini menggunakan metode analisis kuantitatif data non parametric. Metode ini digunakan karena jumlah sampel yang digunakan relative kecil jumlahnya. Populasi yang diambil memiliki varian yang berbeda. Pengujian yang digunakan adalah uji Wilcoxon. 
HASIL

Hasil dari pemberian perlakuan strategi modeling menunjukkan peningkatan kategori. Hasil pre-test dan post-test adalah responden AF dari 66 menjadi 89, responden FNA dari 70 menjadi 90, responden DA dari 75 menjadi 111, responden MEA dari 70 menjadi 116, responden EPP dari 71 menjadi 117, responden IR dari 74 menjadi 98, responden IA dari 76 menjadi 96, responden MRI dari 61 menjadi 96, responden RA dari 52 menjadi 97, responden RAP dari 67 menjadi 90, responden TU dari 65 menjadi 96, responden TNM dari 75 menjadi 100, responden YA dari 69 menjadi 101.Prosentase kenaikannya sebesar $30,92 \%$

Terjadi peningkatan rerata (mean) score variabel pemahaman karier siswa (post-test) setelah diberikan strategi modeling, rerata (mean) score variabel pemahaman karier siswa (pre-test) sebelum diberikan pelatihan strategi modeling 68,79 , sedangkan rerata (mean) score variabel pemahaman karier siswa (post-test) setelah diberikan strategi modeling 99,71 terjadi peningkatan rerata (mean) score variabel pemahaman karier siswa 30,92\% dengan demikian strategi modeling dapat meningkatkan pemahaman karier siswa.

Hasil dari post-test yang telah diberikan kepada 14 responden penelitian hanya mengalami peningkatan pemahaman karier dalam kategori sedang 12 responden dan kategori tinggi 2 responden dengan presentase $30,92 \%$.

\section{PEMBAHASAN}

Sukardi (2008), menje;askan bahwa bimbingan kelompok adalah bimbingan yang memungkinkan sejumlah peserta didik secara bersama-sama memperoleh berbagai bahan dari nara sumber tertentu (terutama dari pembimbing atau konselor) yang berguna untuk menunjang kehidupannya sehari-hari baik individu maupun sebagai pelajar, anggota keluarga dan masyarakat serta untuk pertimbangan dalam pengambilan keputusan. Winkel dan Hastuti (2004) Bimbingan Kelompok adalah kegiatan kelompok diskusi yang menunjang perkembangan pribadi dan perkembangan sosial masing- 
masing individu-individu dalam kelompok, serta meningkatkan mutu kerja sama dalam kelompok guna aneka tujuan yang bermakna bagi para partisipan. Kesimpulan dari pendapat-pendapat di atas bahwa bimbingan kelompok adalah salah satu teknik dalam bidang bimbingan konseling yang berfungsi untuk memberikan bantuan kepada siswa yang dilakukan oleh seorang pembimbing atau konselor melalui kegiatan kelompok yang dapat berguna untuk mencegah berkembangnya masalah-masalah yang dihadapi anak.

Pertemuan dalam bimbingan kelompok ini terbagi menjadi $4 \mathrm{X}$ pertemuan dengan rincian sebagai berikut, pertemuan pertama memberikan video tentang pemahaman karier dan prinsip perencanaan karier, pertemuan kedua memberikan video tentang pemahaman karier, bagaimana perjuangan untuk menjadi dokter, perjuangan dokter di Indonesia, bagaimana menjadi seorang leadership yang dicintai oleh teamnya, dan training kepemimpinan, pertemuan ketiga memberikan video tentang pemahaman karier, bagaimana seorang mekanik pesawat menjalankan pekerjaannya, dan kisah sukses pegawai bank, pertemuan keempat memberikan pembuatan ringkasan tentang apa yang didapatkan dari pertemuan awal sampai akhir.

Pengertian pemahaman karier menurut (dalam Khoiriyah, 2012) bahwa pemahaman karier (occupational knowledge) adalah derajat penguasaan siswa tentang dunia karier yang ditandai dengan pengenalan mendalam mengenai berbagai informasi karier.Berdasarkan teori pendapat para ahli diatas peneliti menyimpulkan pemahaman karier adalah penguasaan seseorang tentang karier berdasarkan informasi karier yang diperoleh sehingga seseorang tersebut mampu memilih karier yang tepat sesuai dengan bakat dan minat.

Menurut John Holland (dalam Tarsidi, 2010), individu tertarik pada suatu karir tertentu karena kepribadiannya dan berbagai variabel yang melatarbelakanginya. Pada dasarnya, pilihan karir 
merupakan ekspresi atau perluasan kepribadian ke dalam dunia kerja yang diikuti dengan pengidentifikasian terhadap stereotipe okupasional tertentu.Teori Holland memberikan penekanan pada ketepatan pemahaman diri (selfknowledge) dan informasi karier yang diperlukan untuk pembuatan keputusan karier. Dampaknya sangat besar pada prosedur asesmen minat dan prosedur konseling karier.Implikasinya untuk konseling adalah bahwa tujuan utama konseling adalah mengembangkan strategi untuk meningkatkan pengetahuan tentang diri, berbagai persyaratan okupasional dan berbagai macam lingkungan kerja. Holland membagi individu menjadi beberapa tipe kepribadian, diantaranya: Tipe Realistik (The Realistic Type), Tipe Peneliti/Pengusut (The Investigative Type), Tipe Seniman (The Artistic Type), Tipe Sosial (The Social Type), Tipe Pengusaha (The Enterprising Type), dan Tipe Orang Rutin (Conventional Type) (http://dtarsidi.blogspot.com, diakses tanggal 4 Agustus 2014 pukul 11.00 WIB).
Melalui pemberian strategi modeling yang memberikan gambaran tentang dunia karier. Maka individu akan memahami bagaimana dirinya agar bisa mengetahui minat dan bakat serta bagaimana dunia kerja. Dari korelasi pemahaman diri dan karier akan membantu individu mengarahkan perencanaan kariernya. Modeling simbolik ini dikemas dalam bentuk bimbingan kelompok.

\section{SIMPULAN}

Berdasarkan hasil penelitian penulis menyimpulkan bahwa adanya pengaruh yang signifikan penggunaan strategi modeling terhadap pemahaman karier siswa kelas X SMK Al-Islah Surabaya. Hal tersebut dapat dibuktikan dari peningkatan kriteria konseli yang asalnya rendah menjadi sedang bahkan ada yang asalnya sedang menjadi tinggi, meskipun tidak semua konnseli mendapatkan kriteria tinggi tetapi sudah ada peningkatan dari semua konseli. Ketidaksamaan tersebut dikarenakan adanya perbedaan latar belakang dari masing-masing konseli. 


\section{DAFTAR PUSTAKA}

Khoiriyah. Nursalim. 2012. Meningkkatkan pemahaman karier siswa dengan pemberian layanan Informasi Karier Di Kelas XI IS -4 SMA Negeri 13 Surabaya. (Online), (http://www.scribd.com/doc/12 4878157, diakses 14 Agustus 2014 pukul 01.00 WIB).

Arikunto, S. 2009. Dasar-Dasar Evaluasi Pendidikan. Jakarta: Bumi Aksara.

Azwar, S. 2012. Penyusunan Skala Psikologi (Edisi 2).
Yogyakarta: Pustaka Pelajar.
Tarsidi. 2010. Teori Perkembangan Karier. (Online), (http://dtarsidi.blogspot.com, diakses tanggal 4 Agustus 2014 pukul $11.00 \mathrm{WIB})$.

Sukardi, Dewa Ketut. 2008. Pengantar pelaksanaan program bimbingan dan konseling disekolah. Jakarta: Rineka Cipta.

Winkel. W.S, Hastuti Sri M.M. 2006. Bimbingan dan Konseling Di Institusi Pendidikan. Yogyakarta: Media Abadi. 
